\title{
Digital Learning among Postgraduate Students in the Times of COVID-19: A Literature Review
}

\author{
Dasinta Seladorai, Maslawati Mohamed \\ Univerisiti Kebangsaan Malaysia (UKM), Bangi, Selangor, Malaysia \\ Email: dasintaseladorai@gmail.com
}

How to cite this paper: Seladorai, D., \& Mohamed, M. (2021). Digital Learning among Postgraduate Students in the Times of COVID-19: A Literature Review. Creative Education, 12, 1494-1502. https://doi.org/10.4236/ce.2021.127114

Received: June 15, 2021

Accepted: July 6, 2021

Published: July 9, 2021

Copyright $\odot 2021$ by author(s) and Scientific Research Publishing Inc. This work is licensed under the Creative Commons Attribution-NonCommercial International License (CC BY-NC 4.0). http://creativecommons.org/licenses/by-nc/4.0/ (c) (i) (5) Open Access

\begin{abstract}
COVID-19, as a global pandemic has caused a dramatic change in the education landscape. With significant policies such as social distancing and movement restrictions, all educational institutions have been shut to flatten the curve. As a response to the unprecedented crisis, digital learning has been given rise to pushing behind conventional classes from primary to tertiary levels. The adoption of online lessons and digital classrooms has mechanized a new pattern of teaching and learning mediated by today's educators in most universities, polytechnics, and colleges. The educators and students are facing the ripple effects of the sudden shift to digital learning. Some postgraduate students seemed to recognize and prepare to embrace the dramatic shift. In any case, some were hesitant to move from customary figuring out ways to embrace digital learning. Therefore, several articles discussing impacts and challenges from postgraduate students' perspectives were summarized. Most of the current research recommended digital learning as one splendid approach to adapt during the pandemic period. Besides, study showed postgraduates' undergoing an assimilation process with the new norm introduced. Furthermore, existing research highlights postgraduate student's challenges such as technological difficulties, health, and lack of interaction. Thus, this paper aims to provide a literature review on digital learning from postgraduate student's perspectives of various papers and indicate the way forward.
\end{abstract}

\section{Keywords}

Digital Learning during COVID-19, Digital Platforms, Tertiary Level

Education, Postgraduate Students, Impacts and Challenges

\section{Introduction}

The World Health Organisation (WHO, 2021) had declared the transmission of 
an infectious disease known as coronavirus disease (COVID-19). The disease had spread globally with 175,184,844 (Worldometer, 2021). Considering this, most governments across the world have announced the first Movement Control Order (MCO) in the mid of March 2020, to prevent any mass gatherings and all crowd meetings. To moderate the spread of the dangerous infection, most governments had temporarily shut all educational institutions forbidding physical learning. Sintema (2020), describes public care strategies as a must to flatten the curve and mitigate the channeling of this infective virus. The unexpected closure of educational institutions, coerced alternative teaching method to be proceeded within this pandemic era (Aboagye, Yawson, \& Appiah, 2021). This resulted in the rise of digital learning pushing behind conventional classes from primary to tertiary levels. The adoption of online lessons and digital classrooms has mechanized a new pattern of teaching and learning mediated by today's educators in most universities, polytechnics, and colleges.

The pandemic outbreak has altered the education landscape distinctly the tertiary learning. The tertiary level educational system worldwide has witnessed an educational disruption on a large scale as physical learning had been prohibited due to the coronavirus (COVID-19) outbreak. Jacob, Abigeal \& Lydia (2020), disclosed that the academic calendar of higher institutions across the globe in the year 2020 was in disarray due to the closure of all educational institutions. The emergency possibility to ensure students is not left idle, since the crisis was the introduction to remote teaching via online platforms. The unprecedented scenario has sprawled a massive transformation on the learning system based on the "new norm" introduced (Pokhrel \& Chhetri, 2021). Digital learning appears to highlight the centrality also reveals the important sides of online learning experiences. Most of the higher education system is operating through e-learning (Azzi-Huck \& Shmis, 2020; Shahzad et al., 2020). Shahzad, Hassan, Aremu, Hussain, \& Lodhi (2020) stated, most of the universities are providing digital courses via platforms such as websites, learning portals, video conferencing, YouTube, mobile apps, and thousand types of free available websites for e-learning tools within and off courses. However, the shift to online mode has raised many queries on the quality of education (Sahu, 2020). This unexpected shift has led to a survival condition to adapt to the new norm without knowing the effectiveness among the tertiary level students.

As a result, this literature review will highlight the effectiveness of digital learning among postgraduate students' during the pandemic era. Then, the review of literature will continue to identify the challenges of digital learning from postgraduate students' perspectives. The ripple effects facing by postgraduate students should not be overlooked as the sudden change did not spare students with time and mental readiness (Al-Okaily et al., 2020). Furthermore, Adedoyin \& Soykan (2020) affirm, the acceptance and adaptation towards digital learning and changes in learning methods can be a dilemma among postgraduates', especially in a remote scenario. In addition, e-learning experience becomes produc- 
tive only with quality interaction between instructors and learners making the transfer of knowledge and feedback fruitful (Baber, 2020). Thus, this review explores the effectiveness and challenges of digital learning among postgraduate students in the times of COVID-19. The review ends with suggestion for way forward for future studies.

\section{Methodology}

For the search of references for this literature review, several databases were utilized. The process started with a search in the databases Google Scholar and Education Resources Information Centre (ERIC). Primarily, expansive inquiry terms were utilized to draw up a rundown of study papers that were essential and relatable. Publications with the term "digital learning" (or the terms "online learning" or "e-learning" or "web-based learning" or "remote learning” or "distance learning" or "virtual learning") and "learning during pandemic" (or the terms "in the times of COVID-19" or "pandemic COVID-19") were sought. The data collected using the keywords were considered relevant for the purpose of this study of examining on digital learning in a remote scenario due to the pandemic announced. Tables were used to analyze the relationship with subtopics contained in the papers gathered. The sources as well as information gathered were dissected and partitioned in like manner. In the gathered articles, information found is generally viable with the target of my review paper. The results obtained via the gathering of literature, provide an overview of the examined research literature on digital learning during the pandemic COVID-19 and the challenges in the context of tertiary education from the postgraduate students' perspectives.

\section{Literature Review Findings and Discussion}

\section{Education in Emergency: Digital Learning}

Mazlan, Mohamad, Reesha, Kassim, Othman \& Kummin (2021) argue that online distant educating and learning is the most feasible plan to be carried out during the period of physical isolation and social distancing announced as a measure to break the chain. Tertiary institutions to consolidate and adjust in with the current crisis have adapted "education in emergency" (Pokhrel \& Chhetri, 2021). Grand-Clement (2017) in his report entitled "Digital Learning: Education and Skills in the Digital Age" portrays that digital learning holds the meaning of penetrating the education and domains with technology gradually delivering knowledge, expertise, and content. This learning mode does not require face-to-face interaction or being physically present to impart knowledge. The hike of digital platforms had ushered the new paradigm of teaching and learning (Adedoyin \& Soykan, 2020). The noticeable progress managed to escalate the shift towards digital learning offering online courses to meet the demands of curriculum despite the crisis. Beckmann (2020) claims that virtual classes are being conducted interactively via digital platforms such as Microsoft 
Teams, Zoom, Google Meet and MOOC. These applications enable lessons to be delivered lively as it used to be in mass lectures and had its own transfer of knowledge effectively. Jena, P.K. (2020), argues that digital learning has transformed lives by providing flexible places, class timings and quality content. However, the transitioning from the customary practice of physical learning to digital learning mediated by technology and gadgets can be an entirely different experience for educators and learners. Hodges, Moore, Lockee, Trust \& Bond (2020) in their recent study stated, the speed of moving and adapting to the change of mode in tertiary education can be slow and staggering. In addition, Manco-Chavez, Uribe-Hernandez, Buendia-Aparcana, R. Joaquin, Vertiz-Osores \& Rengifo-Lozano (2020), claim that learners were not given any choice but to relearn their ways to cope with digital learning. Therefore, learners would have unquestionably gone through a gradual domino effect, rising queries about the viability of digital learning due to the startling scenario.

\section{Challenges}

The success of any information system depends on the usage of the system by users (Almaiah, 2018). In view of that fact, the success and effectiveness of the digital platforms relies on learners and educator's acceptance towards the web-based learning using the technological gadgets available. Markova, Glazkova \& Zaborova (2017) state that, tertiary education has always provided ever continuous demand for knowledge and comprehensive human resource in the global market. With that, the rapid development in the global market has always reassured the modes of education, especially in the tertiary level. Machin \& McNally (2007) claim that Malaysia has been listed as one of the universities in South East Asia that has constantly redefined the goals and objectives of education to provide increasing supply of tertiary graduates. However, the sudden shift which is switching from face to face class to digital learning overnight hastily might not be fair to the learners. Learners certainly have their own perception of online learning during this COVID-19 pandemic (Allo, 2020). The study results of Tareen \& Haand (2020) reveals that digital learning is helpful, caters students' needs and promotes interaction. Nevertheless, the study also uncovers absence in precise feedback and support that led students to a detached scenario from the learning environment. Other than that, the study by Dhawan (2020), points out that there are various technological options available, still comes with challenges to deal with from a student's perspective. Ultimately, digital learning is a recognizable category of working solution to prevent education from being halted however the success is yet to prevail.

\section{Technology}

A technology that lies under the umbrella of e-learning has made it possible to continue the learning process during the lockdown (Zwain, 2019). In this tough era, dealing with technology can be troublesome. Dhawan (2020), pointed out technological difficulty that can jeopardize digital learning. Initially, students could face technological issues such as failure in downloading applications and 
files, installation errors, logging identity document (ID) errors and problems with their own gadgets. This uncommon emergency could keep them held from joining digital classes. Next, the lack of accessibility to stable internet connection can influence students' performance and efficacy. The study by Chen, Kaczmarek \& Ohyama (2020) indicated polling results that opted for synchronous recorded live lectures and prerecorded lectures since their learning got worsened with poor internet connection. This highlights, digital equity tends to be the barrier in allowing digital learning despite the crisis. Aljarrah, Ababneh \& Cavus (2020) reveal that tertiary institutions as colleges and universities are more prone in acknowledging and utilizing various Learning Management Systems (LMS) resulting in active online learning. This technology is referred to various learning management system available online that promotes online learning, interaction and accessibility to materials via the internet (Cavus, Mohammed, \& Yakubu, 2021). The study on "The role of massive open online courses during the COVID-19 era: Challenges and perspective" by Cavus, Sani, Haruna, and Lawan (2021), points out that MOOC (Massive Open Online Courses) is intended for learning goals whereby students' will be assigned to complete tasks along with asynchronous interacting features. Nevertheless, the study by Yunus, Hashim, Ahmad, Sulaiman, Fadzila, Nurfitri \& Hasmirah (2018) revealed that unstable internet connection and time constraints tend to be the significant hindrances for learning engagement. Thus, embracing the transition can be difficult for learners who cannot afford for stable internet connection or access.

\section{Health}

Maatuk et al. (2021) affirm that, Information and communication technologies (ICT) promotes openings for advanced and instructive lessons that lead to improved teaching and learning outcomes. For the past 20 years, various impressive exploration concerning digital learning existed in higher institutions however the sudden digitization would have thrown students off their guard without adequate experience (Fawaz \& Samaha, 2021). The alarming situation due to the outbreak of COVID-19 can affect learners' health physically and mentally. This is because, studying digitally day and night simultaneously being physically isolated can deteriorate health severely. According to the results obtained from a recent study entitled "Effects of COVID-19 on College Students' Mental Health in the United States" by Son, Hegde, Smith, Wang \& Sasangohar (2020) out of 195 participants 71 percent of students reported the increase in stress and anxiety. Meanwhile, 82 percent of students had reported fear concerning their grades and performances via digital learning. This clearly stresses the concern that should be focused on learner's health throughout the digital learning phase. Similarly, the study by Wang, Hegde, Son, Keller, Smith, \& Sasangohar (2020), procured postgraduates are at higher risk of experiencing depression, anxiety and acute stress with suicidal thoughts due to the shift of learning and the crisis situation of COVID-19. The alarming response and concerns on academic, health and lifestyle should be well understood and addressed. 
In addition, Telmesani, Ahmad \& Telmesani (2017), listed out physical impacts of technology in their recent study. Sitting and staring at bright screens can affect one's eyesight. They claim that Computer Vision Syndrome (CVS) is a familiar syndrome diagnosed among people who tend to use gadgets with screen. It is said that people tend to intently focus on the screen and ignore the blinking process which can lead to the syndrome mentioned. Therefore, the considerable impacts raise concerns on postgraduate learners' well-being throughout the digital learning phase (Imran, Masood, Ayub, \& Gondal, 2020).

\section{Interaction}

Most digital learning platform guarantees learning to be effective and student-friendly (Gautam, 2020). Gaebel, Kupriyanova, Morais and Colucci (2014) claim, digital learning in an enhanced educational setting offers various platforms and devices to support learning. Kitada, Dalaklis, Ballini, \& Canepa (2021), argue the theory connectivism promotes digital learning and explores socialization among learners via cyberspace however, it does not imply that students can attain benefit in real scenarios. This is because, the study by Aljawarneh (2020), indicated the advent of digital learning platforms and resources neglected to foster healthy interaction among instructors-students, students-instructors, and students-students. To view the fact that, interaction aids remote teaching and learning Alqurashi (2019) points out that interaction is an important determinant of student perceived learning and satisfaction. The study results of Bahasoan, Ayuandiani, Mukhram \& Rahmat (2020), highlights that $48 \%$ of the respondents felt digital learning is effective and inefficient due to the barriers in socialization. Sharin (2021), claims that two-way communication can be difficult to enforce at times, leaving learners unbothered due to circumstances. Therefore, the replacement for the traditional learning of face-face can impede interaction from taking place as it was before the sudden shift.

\section{Conclusion}

The coronavirus pandemic has completely altered the tertiary education landscape. Postgraduate students are confronting difficulties because of the abrupt episode of the sudden shift. This review has highlighted, the challenges faced by postgraduate students during this pandemic flare-up. The significance of understanding and addressing students' barriers in embracing digital learning such as technology, health and lack of interaction will propel the splendid side of digital learning. Digital learning needs to be able to address learners' needs across several disciplines in higher education. To conclude, the findings procured in this study, will enable policy makers and decision makers to foster decent arrangements and measures to guarantee the viability of digital learning among postgraduate students in the times of COVID-19. By that, the education experts will be able to reshape the curriculum and the mode of transfer enabling 100 percent of success via digital learning. 


\section{Conflicts of Interest}

The authors declare no conflicts of interest regarding the publication of this paper.

\section{References}

Aboagye, E., Yawson, J. A., \& Appiah, K. N. (2021). COVID-19 and E-Learning: The Challenges of Students in Tertiary Institutions. Social Education Research, 1, 1-8. https://doi.org/10.37256/ser.122020422

Adedoyin, O. B., \& Soykan, E. (2020). COVID-19 Pandemic and Online Learning: The Challenges and Opportunities. Interactive Learning Environments, 1-13. https://doi.org/10.1080/10494820.2020.1813180

Aljarrah, A. A., Ababneh, M. A.-K., \& Cavus, N. (2020). The Role of Massive Open Online Courses during the COVID-19 Era: Challenges and Perspective. New Trends and Issues Proceedings on Humanities and Social Sciences, 7, 142-152. https://doi.org/10.18844/prosoc.v7i3.5244

Aljawarneh, S. A. (2020). Reviewing and Exploring Innovative Ubiquitous Learning Tools in Higher Education. Journal of Computing in Higher Education, 32, 57-73. https://doi.org/10.1007/s12528-019-09207-0

Allo, M. D. (2020). Is the Online Learning Good in the Midst of COVID-19 Pandemic? The Case of EFL Learners. Jurnal Sinestesia, 10, 1-10.

Almaiah, M. A. (2018). Acceptance and Usage of a Mobile Information System Services in University of Jordan. Education and Information Technologies, 23, 1873-1895. https://doi.org/10.1007/s10639-018-9694-6

Al-Okaily, M., Alqudah, H., Matar, A., Lutfi, A., \& Taamneh, A. (2020). Dataset on the Acceptance of e-Learning System among Universities Students' under the COVID-19 Pandemic Conditions. Data in Brief, 32, Article ID: 106176. https://doi.org/10.1016/j.dib.2020.106176

Alqurashi, E. (2019). Predicting Student Satisfaction and Perceived Learning within Online Learning Environments. Distance Education, 40, 133-148. https://doi.org/10.1080/01587919.2018.1553562

Azzi-Huck, K., \& Shmis, T. (2020). Managing the Impact of COVID-19 on Education Systems around the World: How Countries Are Preparing, Coping, and Planning for Recovery. https://blogs.worldbank.org/education/managing-impact-COVID-19-education-syste msaround-world-how-countries-are-preparing

Baber, H. (2020). Determinants of Students' Perceived Learning Outcome and Satisfaction in Online Learning during the Pandemic of COVID-19. Journal of Education and E-Learning Research, 7, 285-292. https://doi.org/10.20448/journal.509.2020.73.285.292

Bahasoan, A. N., Ayuandiani, W., Mukhram, M., \& Rahmat, A. (2020). Effectiveness of Online Learning in Pandemic COVID-19. International Journal of Science, Technology \& Management, 1, 100-106. https://doi.org/10.46729/ijstm.v1i2.30

Beckmann, A. (2020). Students Views on Digital Tools in University Lectures. Proceedings of INTED 2020 Conference, Valencia, 2-4 March 2020, 375. https://doi.org/10.21125/inted.2020.0159

Cavus, N., Mohammed, Y. B., \& Yakubu, M. N. (2021). Determinants of Learning Management Systems during COVID-19 Pandemic for Sustainable Education. Sustainability, 13, 5189. https://doi.org/10.3390/su13095189

Cavus, N., Sani, A. S., Haruna, Y., \& Lawan, A. A. (2021). Efficacy of Social Networking 
Sites for Sustainable Education in the Era of COVID-19: A Systematic Review. Sustainability, 13, 808. https://doi.org/10.3390/su13020808

Chen, E., Kaczmarek, K., \& Ohyama, H. (2020). Student Perceptions of Distance Learning Strategies during COVID-19. Journal of Dental Education, 85, 1190-1191. https://doi.org/10.1002/jdd.12339

Dhawan, S. (2020). Online Learning: A Panacea in the Time of COVID-19 Crisis. Journal of Educational Technology Systems, 49, 5-22. https://doi.org/10.1177/0047239520934018

Fawaz, M., \& Samaha, A. (2021). E-Learning: Depression, Anxiety, and Stress Symptomatology among Lebanese University Students during COVID-19 Quarantine. Nursing Forum, 56, 52-57. https://doi.org/10.1111/nuf.12521

Gaebel, M., Kupriyanova, V., Morais, R., \& Colucci, E. (2014). E-Learning in European Higher Education Institutions: Results of a Mapping Survey Conducted in October-December 2013.

Gautam, P. (2020). Advantages and Disadvantages of Online Learning. eLearning Industry.

Grand-Clement, S. (2017). Digital Learning: Education and Skills in the Digital Age. Cambridge: RAND Europe. https://doi.org/10.7249/CF369

Hodges, C., Moore, S., Lockee, B., Trust, T., \& Bond, A. (2020). The Difference between Emergency Remote Teaching and Online Learning. Educause Review, 27, 1-12.

Imran, N., Masood, H. M. U., Ayub, M., \& Gondal, K. M. (2020). Psychological Impact of COVID-19 Pandemic on Postgraduate Trainees: A Cross-Sectional Survey. Postgraduate Medical Journal, 1-6.

https://doi.org/10.1136/postgradmedj-2020-138364

Jacob, O. N., Abigeal, I., \& Lydia, A. E. (2020). Impact of COVID-19 on the Higher Institutions Development in Nigeria. Electronic Research Journal of Social Sciences and Humanities, 2, 126-135.

Jena, P. K. (2020). Online Learning during Lockdown Period for COVID-19 in India. International Journal of Multidisciplinary Educational Research (IJMER), 9, 82-92. https://doi.org/10.31235/osf.io/qu38b

Kitada, M., Dalaklis, D., Ballini, F., \& Canepa, M. (2021). Maritime and Ocean Postgraduate Education during the COVID-19 Pandemic: Opportunities and Challenges Associated with Online Delivery of Lectures. Proceedings of INTED2021 Conference, Vol. 8, 9. https://doi.org/10.21125/inted.2021.0727

Maatuk, A. M., Elberkawi, E. K., Aljawarneh, S., Rashaideh, H., \& Alharbi, H. (2021). The COVID-19 Pandemic and E-Learning: Challenges and Opportunities from the Perspective of Students and Instructors. Journal of Computing in Higher Education, 1-18.

Machin, S., \& McNally, S. (2007). Tertiary Education Systems and Labour Markets (p. 6). Paris: Education and Training Policy Division, OECD.

Manco-Chavez, J. A., Uribe-Hernandez, Y. C., Buendia-Aparcana, R., Joaquin, J., Vertiz-Osores, S. D. I. A., \& Rengifo-Lozano, R. A. (2020). Integration of ICTS and Digital Skills in Times of the Pandemic COVID-19. International Journal of Higher Education, 9, 11-20. https://doi.org/10.5430/ijhe.v9n9p11

Markova, T., Glazkova, I., \& Zaborova, E. (2017). Quality Issues of Online Distance Learning. Procedia-Social and Behavioral Sciences, 237, 685-691. https://doi.org/10.1016/j.sbspro.2017.02.043

Mazlan, A. F., Mohamad, M., Reesha, A., Kassim, R., Othman, Z., \& Kummin, S. (2021). Challenges and Strategies to Enhance Online Remote Teaching and Learning by Ter- 
tiary Institution Educators: A Literature Review. Creative Education, 12, 718-726. https://doi.org/10.4236/ce.2021.124050

Pokhrel, S., \& Chhetri, R. (2021). A Literature Review on Impact of COVID-19 Pandemic on Teaching and Learning. Higher Education for the Future, 8, 133-141. https://doi.org/10.1177/2347631120983481

Sahu, P. (2020). Closure of Universities Due to Coronavirus Disease 2019 (COVID-19): Impact on Education and Mental Health of Students and Academic Staff. Cureus, 12, e7541. https://doi.org/10.7759/cureus.7541

Shahzad, A., Hassan, R., Aremu, A. Y., Hussain, A., \& Lodhi, R. N. (2020). Effects of COVID-19 in E-Learning on Higher Education Institution Students: The Group Comparison between Male and Female. Quality \& Quantity, 55, 805-826. https://doi.org/10.1007/s11135-020-01028-z

Sharin, A. N. (2021). E-Learning during COVID-19: A Review of Literature. Jurnal Pengajian Media Malaysia, 23, 15-28.

Sintema, E. J. (2020). Effect of COVID-19 on the Performance of Grade 12 Students: Implications for STEM Education. Eurasia Journal of Mathematics, Science and Technology Education, 16, em1851. https://doi.org/10.29333/ejmste/7893

Son, C., Hegde, S., Smith, A., Wang, X., \& Sasangohar, F. (2020). Effects of COVID-19 on College Students' Mental Health in the United States: Interview Survey Study. Journal of Medical Internet Research, 22, e21279. https://doi.org/10.2196/21279

Tareen, H., \& Haand, M. T. (2020). A Case Study of UiTM Post-Graduate Students' Perceptions on Online Learning: Benefits \& Challenges. International Journal of Advanced Research and Publications, 4, 86-94.

Telmesani, M., Ahmad, W., \& Telmesani, T. M. (2017). The Impact of Technology on Minors: A Survey-Based Study. Australasian Journal of Business, Social Science and Information Technology, 3, 78-90.

Wang, X., Hegde, S., Son, C., Keller, B., Smith, A., \& Sasangohar, F. (2020). Investigating Mental Health of US College Students during the COVID-19 Pandemic: Cross-Sectional Survey Study. Journal of Medical Internet Research, 22, e22817. https://doi.org/10.2196/22817

World Health Organization (2021). The WHO STEPwise Approach to Surveillance (No. WHO/EURO: 2021-2446-42201-58182). Geneva: World Health Organization, Regional Office for Europe.

Worldometer, D. (2021). COVID-19 Coronavirus Pandemic. Geneva: World Health Organization. https://www.worldometers.info

Yunus, M. M., Hashim, H., Ahmad, A. R., Sulaiman, N. A., Fadzila, A. S., Nurfitri, A., Hasmirah, N. et al. (2018). MOOC as a Platform for Developing Writing Skills: Effectiveness and Challenges. Advanced Science Letters, 24, 199-201. https://doi.org/10.1166/asl.2018.11958

Zwain, A. A. A. (2019). Technological Innovativeness and Information Quality as Neoteric Predictors of Users' Acceptance of Learning Management System: An Expansion of UTAUT2. Interactive Technology and Smart Education, 16, 239-254.

https://doi.org/10.1108/ITSE-09-2018-0065 